\title{
Ethnobotanical Knowledge of Malayali Tribes in Jawadhu Hills- An Analysis
}

\author{
T. Prabu ${ }^{1}$, S. Madhavan ${ }^{2}$ and P. Pachaiyappan ${ }^{3}$ \\ ${ }^{1}$ Research Scholar, Research \& Development Centre, Bharathiar University, Coimbatore, Tamilnadu, India \\ ${ }^{2}$ Department of Botany, Government Arts College, Kumbakonam, Tamilnadu, India \\ ${ }^{3}$ Research Scholar, Institute of Advanced Study in Education, Saidapet, Chennai, Tamilnadu, India
}

\begin{abstract}
The present investigation highlights the use of plants for various ailments by malayali tribe living in Jawadhu hills, Thiruvannamalai district, Tamilnadu, India, A total of 40 traditional plant species used by them as herbal medicines to treat several common diseases such as cold, cough, fever, skin diseases, rheumatic problems, diabetic problems and various ailments were documented. During present study it has been observed that the ethno botanical systems and herbal medicines as therapeutic agents are of a paramount importance of addressing the health problems of traditional communities. The indigenous knowledge available with these people plays an important role in quick and proper identification of natural resources. Methods: The extensive field survey was carried out in the Jawadhu hills. The 124 Malayali tribes were selected in this study for collecting the ethnobotanical data through the questionnaires, discussions, and personal interviews during the regular field trips. Results and discussion: The study reveals that about 40 medicinal plants belonging to 27 families have been documented with the scientific name, family name, vernacular name (Tamil name) and various plant parts used by the malayali local tribes of Jawadhu hills for the treatment of many diseases. Conclusion: We observed and analyzed that the documented ethno medicinal plants were used to cure various diseases such as cold, fever, jaundice, asthma, ulcer, diabetes, and cancer treatment by the local malayali tribes of Jawadhu hills.
\end{abstract}

Keywords: Ethno botany, Malayali tribes, Jawadhu hills, Ethno botanical knowledge, Ethnomedicine

\section{Introduction}

The term "Ethnobotany" was coined by J.W. Harshberger in 1896 to indicate plants used by the aboriginals: From "ethno"-study of people and "botany"-study of plants. Ethnobotany is considered as a branch of ethnobiology. It deals with the study and evaluation of plant human relations in all phases and the effect of plant environment on human society. Tamil Nadu has rich biodiversity consisting of a large number of plants, some of which are used for their medicinal value. Ethno botany is the study of how the people of a particular culture and regions makes the use of indigenous plants/while the ethno botanist explores how plants are used for food, shelter, medicine, clothing hunting and religious ceremonies. It is the relationship between a given society and its environment and in particular the plant world [1]. According to the world health organization (WHO) more than $80 \%$ of the world's population relies on traditional medicine for their primary health care needs. Use of herbal medicines in Asia represents a long history of human interactions with the environment. Plants used for traditional medicine contain a wide range of substances that can be used to treat chronic as well as infectious diseases. A vast knowledge of how to use the plants against different illnesses may be expected to have accumulated in areas where the use of plants is still of great importance [2].

The objective of the present study is to higlights the ethnobotanical knowledge of Malayali tribes in Jawadhu hills in the state of tamilnadu, India. To analyse the various plant habits used for preparation of medicine. To document the natural resources use pattern of the study area and the ethnomedicinal, indigenous knowledge associated with them. To encourage the local community people to protect and conserve the medicinal plants in this study area.

\subsection{Malayali Tribes}

Malayalis $($ Mala $=$ hill, ali $=$ dwells or inhabits $)$ were belived to have migrated from kanchipuram. There is no unique opinion about the region of the malayali tribe. Evidences regarding the movement of malayali tribal to the jawadhu hills were from Kanchipuram during the pallava period. The myths connected to the migration of malayali tribe into jawadhu hills have been described by Thurston (1909).Actually these were the descriptions of some of the heredity leaders like 'Pattakaran' Sathigoundan and kangani. They are tamil speaking hill tribes and all are mostly agriculturist. Their pure population can be seen in kollihills, yercaud,jawadhuhills, Yelagiri,and Bodemalai. According to Thurston the word Malayali means the inhabitants of hills.Malayali is one of the 36 scheduled tribes of tamilnadu and the population of malayali tribes' forms 
around $54 \%$ of total schedule tribe population of tamilnadu. Most of the malayali tribes have general knowledge of medicinal plants that are used for first aid remedies to various ailments.

\section{Materials and Methods}

Tamilnadu is situated in southern end of India, east of Kerala and south of Andhra Pradesh and Karnataka states. The area of investigation Jawathu hills is located at Thiruvannamalai district, The hills has an area of 2405 sq.km and a population of 8,500 (98\% tribals and others $2 \%$ ) with 11 Panchayat unions and 229 mountainer villages in Jawathu hills Taluk are Jawadhu hills, Kanmalai, Kovilur,Melsilambadi, Nammiyambat, Palamarathur, Puliyur, Thenmalai Athipatu, Veerapanur, Veeragoundur, It is bounded on the East of polur (43 $\mathrm{Kms}$ ), on the West of Amirthi (33Kms), and on the North of Allangayam (25 Kms) in Thiruvannamalai district and a part of the Eastern ghats. The beautiful mountain lies at about 2315 to $3000 \mathrm{mts}$ at the sea level. The jawadhu hill range comprises of hills running from the North to the south attaining a maximum length of 65 $\mathrm{kms}$, and spread within the Districts of thiruvannamalai and Vellore. Temperature varies with in the altitude and ranged from $11^{\circ} \mathrm{c}$ to $44^{\circ} \mathrm{c}$. The maximum temperature raises to in May $44^{\circ} \mathrm{c}$ and minimum lies at $11^{\circ} \mathrm{c}$. The area is well known for excessive rainfall $(\geq 1100 \mathrm{~mm})$ and dry months are rare. The relative humidity remains high varies from 40 to $85 \%$. Jawathu hills have many scenic spots. Places interest in the jawathu hills are Beema Falls, Komutteri Lake, Kavalur observatory, Amirthi Forest,and the Glasshouse.

The data on medicinal plants was recorded through questionnaires, Discussions and personal interviews during the regular field trips with knowledgeable elder people (Malayali tribes) under the age group of 25 to 70 years. The ethno botanical survey was carried out during June 2012 to December 2012 among malayali population residing in this area.(Fig.1.) The information about plants and their local names, parts of plant used for preparation of drug and mode of administration were documented in the field survey. The collected plant species were identified with help of flora books, Voucher specimens are deposited in the herbarium of Botany Department, Government arts college, Kumbakonam.

\section{Results and Discussion}

The present investigation revealed that the malayali tribal of the jawadhuhills region were using 40 plant species belonging to 27 families for medicinal use. The most medicinally important plants species were observed in different families like Apiaceae, Euphorbiaceae, Poaceae, Moraceae, Verbenaceae, Myrtaceae, Meliaceae, Cucurbitaceae, Musaceae, Boraginaceae, Amaranthaceae, Solanaceae, Malvaceae, Araceae, Lilliaceae, Aristolochiaceae, Fabaceae, Vitaceae, Rutaceae, Lamiaceae, Zingiberaceae, Rubiaceae, Apocynaceae, Sapotaceae. The ethno medicinal information of 40 plant species was collected and is enumerated below in the alphabetical order. For each species listed, correct botanical names followed by family name, vernacular name (VN) and medicinal uses are given. They were using these plants to cure disease like chest pain, wounds, pimples, dog bite and poisonous bites (snake, scorpion and insect) pimples, disorders of tooth, cold, cough, fever, jaundice, ulcer, cancer, tuberculosis, piles, diabetes, diarrhoea, asthmatic problems, digestive problems, Scabies, Measles. Most of the drugs are prepared from the wild plants a few interesting observations made in the present study are: the use of Solanum trilobatum and ocimum tenuiflorium for cancer, Ricinnus communis for jaundice, Vitex negundo for asthmatic complaints and poision killer, Syzygium cumini for fever and rheumatic pains, Leucas aspera and Euphorbia hirta for snake bites, Aristolochia bracteolate for skin diseases and syphilis. Although traditional medication is still practised in this area (Table 1).
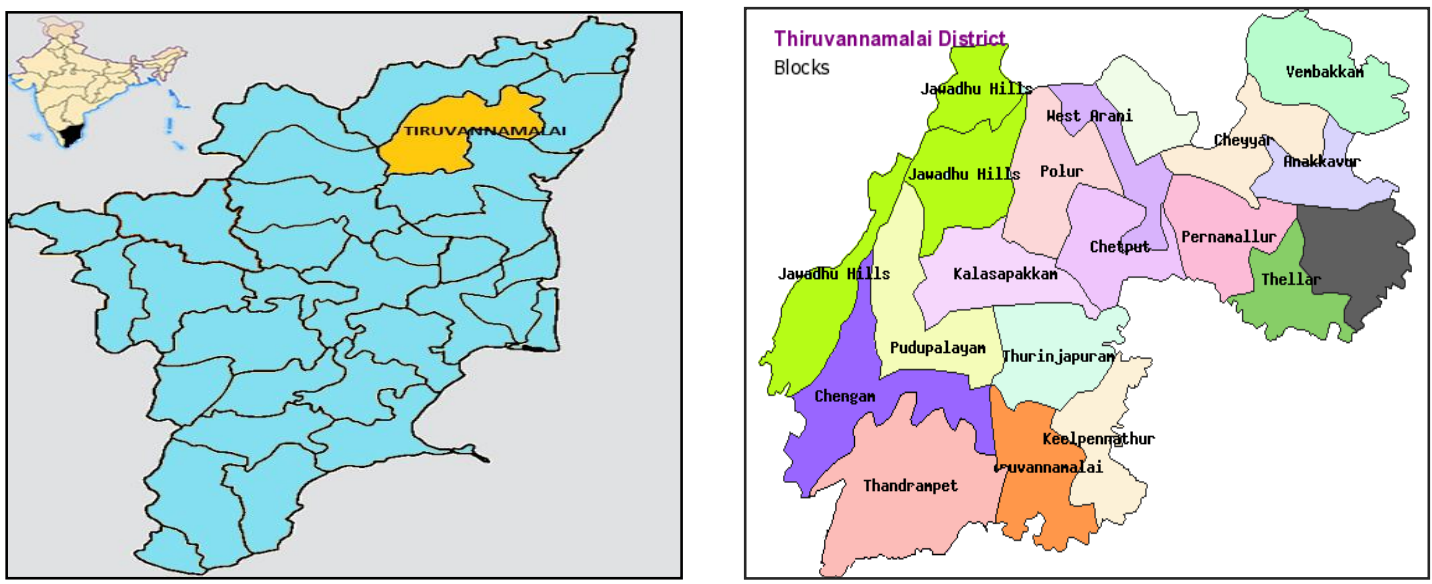

Fig.1: The map shows Jawadhu Hills in Thiruvannamalai District 


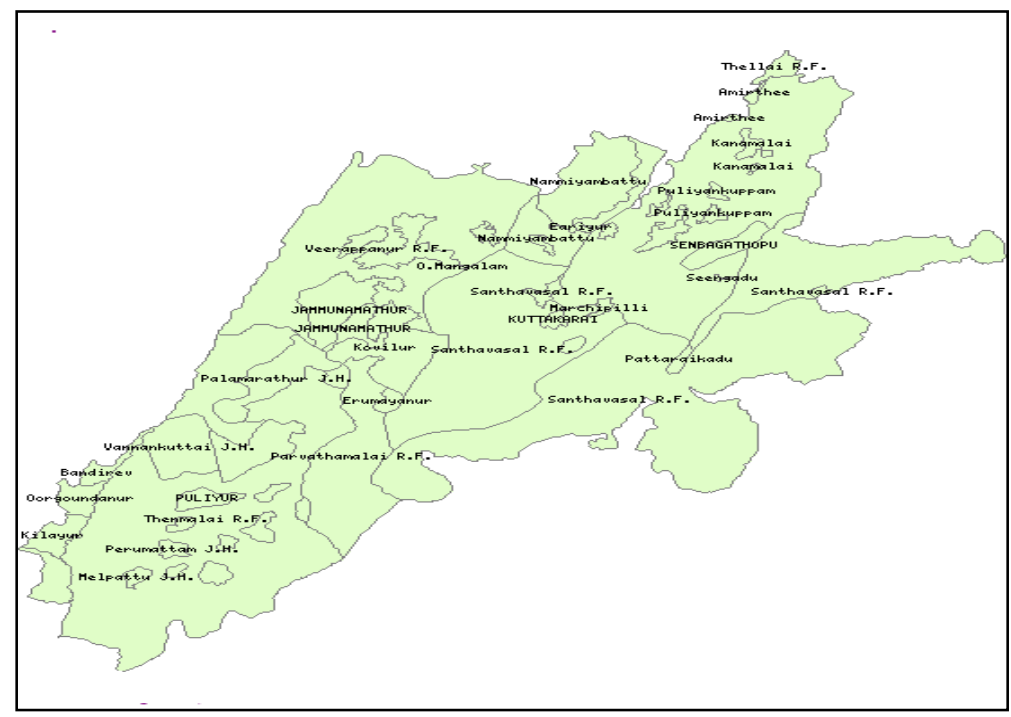

Fig.2: Area map showing the location of Jawadhu Hills in Tamilnadu, India

Table 1: Medicinal plants used for the treatment of various diseases by local people

\begin{tabular}{|c|c|c|c|c|}
\hline $\begin{array}{l}\text { S. } \\
\text { No }\end{array}$ & Scientific name & Family & Local name & Mode of action \\
\hline 1 & Acalypha indica $\mathrm{L}$. & Euphorbiaceae & Kuppamaeni & $\begin{array}{l}\text { Whole plant is used in poison killer for insect } \\
\text { bites }\end{array}$ \\
\hline 2 & Azadirachta indica, A.Juss. & Meliaceae & Vembu & $\begin{array}{l}\text { Plant parts are made in powder and mixed with } \\
\text { jaggery taken orally to cure female sterility. }\end{array}$ \\
\hline 3 & Achyranthus aspera, $\mathrm{L}$ & Amaranthaceae & Nayuruvi & $\begin{array}{l}\text { Paste of leaves is applied on the Ringworm, and } \\
\text { young shoot with onion paste used for Dog bite, } \\
\text { teeth problems }\end{array}$ \\
\hline 4 & Abutilon indicum, $\mathrm{L}$. & Malvaceae & Thuthi & Juice of the leaves cure Fever, allergy, piles \\
\hline 5 & Acorus calamus, L. & Araceae & Vasambu & $\begin{array}{l}\text { The ash of the rhizome is mixed with water or } \\
\text { milk to cure Indigestion. }\end{array}$ \\
\hline 6 & Adathoda vasika, Nees. & Acanthaceae & Adathoda & Paste of the leaves is applied on the wounds. \\
\hline 7 & Aloe vera, $\mathrm{L}$. & Lilliaceae & Sothukathalai & $\begin{array}{l}\text { Fresh leaves or juice of the leaves used as Body } \\
\text { heat and ulcer problems. }\end{array}$ \\
\hline 8 & $\begin{array}{l}\text { Aristolochia bracteolate, } \\
\text { Lam. }\end{array}$ & Aristolochiaceae & Adutheendapalai & $\begin{array}{l}\text { Powder with honey is cure Syphilis, Powder with } \\
\text { castor oil cure Skin diseases }\end{array}$ \\
\hline 9 & Artocarpus integrifolia, $\mathrm{L}$. & Moraceae & Palamaram & The stems of this plant used to Toothbrush. \\
\hline 10 & Bauhinia recemopsa,Lam. & Fabaceae & Malai Aathi & The stems of this plant used to Toothbrush. \\
\hline 11 & Coccinia grandis, $\mathrm{L}$. & Cucurbitaceae & Koovai & Leaves juice taken internally for ulcer, diarrhoea \\
\hline 12 & Centella asiatica $\mathrm{L}$. & Apiaceae & Vallarai & Crushed Leaves are applied externally for wounds \\
\hline 13 & Cassia auriculata, $\mathrm{L}$ & Ceasalpiniaceae & Avaram & The flower juice is used to treat heart pain. \\
\hline 14 & Cissus quadrangularis, $\mathrm{L}$. & Vitaceae & Perandai & Stem juice for cure Asthma. \\
\hline 15 & Citrus aurantifolia, $\mathrm{L}$. & Rutaceae & Elumichai & Fresh fruit juice for indigestion and body heat. \\
\hline 16 & Coccinia indica, $\mathrm{L}$. & Cucurbitaceae & Covai & $\begin{array}{l}\text { Paste of the leaves internally used to cure } \\
\text { diarrhoea. }\end{array}$ \\
\hline 17 & Coleus aromaticus, Bentle. & Lamiaceae & Karpuravalli & $\begin{array}{l}\text { The leaf Juices are used to treat Cold, Cough, } \\
\text { Headache and Asthma. }\end{array}$ \\
\hline 18 & Curcuma langa, $\mathrm{L}$. & Zingiberaceae & Manjal & $\begin{array}{l}\text { Leaf Paste used to cure Skin inflammation, } \\
\text { Wounds, Chicken pox, Measles, Scabies. }\end{array}$ \\
\hline 19 & $\begin{array}{lll}\begin{array}{l}\text { Cyanodon dactylon } \\
\text { pers }\end{array} & (\mathrm{L}) \\
\end{array}$ & Poaceae & Arugampule & Juices of this plant used for digestive problems \\
\hline 20 & Euphorbia hirta, L. & Euphorbiaceae & Ammanpacharisi & Decoction of plant used for Snake bites. \\
\hline 21 & Ficus benghalensis, $\mathrm{L}$. & Moraceae & Alamaram & $\begin{array}{l}\text { Oil extract is applied for Dandruff and Cracks on } \\
\text { the foot. }\end{array}$ \\
\hline 22 & Ficus glomerata, Roxb. & Moraceae & Attimaram & $\begin{array}{l}\text { Plant parts are made in powder and mixed with } \\
\text { milk to drink orally to cure Menorrhoea. }\end{array}$ \\
\hline 23 & Hibiscus rosasinensis, $\mathrm{L}$. & Malvaceae & Semparuthi & $\begin{array}{l}\text { Root decoction for Venereal disease, Flower } \\
\text { decoction for Arterial hypertension, and Anti } \\
\text { fertility, Oil extract of flower for Blackening hair. }\end{array}$ \\
\hline 24 & Heliotropium indicum, $\mathrm{L}$. & Boraginaceae & Thel kodukkai & $\begin{array}{l}\text { Paste of leaves applied externally on the } \\
\text { Ringworm, Pimples problems }\end{array}$ \\
\hline 25 & Ixora coccinea, $\mathrm{L}$. & Rubiaceae & Idlipoo & Oil extract is curing Eczema. \\
\hline 26 & Justica acaulis, L. & Acanthanceae & Nilakadambu & Decoction for Deworming. \\
\hline
\end{tabular}


Ethnobotanical Knowledge of Malayali Tribes in Jawadhu Hills-An Analysis

\begin{tabular}{|c|c|c|c|c|}
\hline 27 & Jatropha curcus, L. & Euphorbiaceae & Kattamanakku & $\begin{array}{l}\text { Leave paste applied externally for Scabies, } \\
\text { Ringworm infection }\end{array}$ \\
\hline 28 & Leucas aspera, $\mathrm{L}$. & Lamiaceae & Thumbai & Juice for Snakebite, Scorpion bite. \\
\hline 29 & Mimosa pudica, L. & Fabaceae & Thottalsurungi & $\begin{array}{l}\text { Decoction for Anti fertility, Paste for Cuts and } \\
\text { wounds. }\end{array}$ \\
\hline 30 & Mimusops elengi, L. & Sapotaceae & Magliam & Decoction of leaves used for Dental diseases. \\
\hline 31 & Musa paradisiaca $\mathrm{L}$. & Musaceae & Vazhai & $\begin{array}{l}\text { Stem are boiled and taken internally for kidney } \\
\text { trouble and bark used for burn wound treatment }\end{array}$ \\
\hline 32 & Momardica charantia, L. & Cucurbitaceae & Pagarkai & Fruits is used to cure reduce blood sugar level. \\
\hline 33 & Melia azedarach, $\mathrm{L}$. & Meliaceae & Malai vembu & $\begin{array}{l}\text { Flowers and seeds used for the treatment of } \\
\text { diabetes }\end{array}$ \\
\hline 34 & Ocimum tenuiflorium $\mathrm{L}$. & Lamiaceae & Thulasi & $\begin{array}{l}\text { Leaves crushed with pepper and mixed with curd } \\
\text { applied internally for cancer. }\end{array}$ \\
\hline 35 & Ocimum basilicum, L. & Lamiaceae & Karunthulasi & $\begin{array}{l}\text { Oil extract of the leaves is curing Eczema, } \\
\text { Scabies, and ear-ache. }\end{array}$ \\
\hline 36 & Ricinnus communis L. & Euphorbiaceae & Amanaku & $\begin{array}{l}\text { Leaves with pepper used for the treatment of } \\
\text { jaundice }\end{array}$ \\
\hline 37 & Syzygium cumini(L) Skeels. & Myrtaceae & Navalmaram & $\begin{array}{l}\text { Bark ground with Neem bark boiled in water } \\
\text { taken internally to get relief from fever and } \\
\text { rheumatic pains }\end{array}$ \\
\hline 38 & Solanum trilobatum, $\mathrm{L}$. & Solanaceae & Tudhuvallai & $\begin{array}{l}\text { Leaf juice used for Cough, fever, cancer, } \\
\text { Tuberculosis problem }\end{array}$ \\
\hline 39 & Vitex negundo, L. & Verbenaceae & Notchi & $\begin{array}{l}\text { Leaves boiled in water taken as inhalation for } \\
\text { asthmatic complaints and used in poison killer. }\end{array}$ \\
\hline 40 & Vinca rosea, L. & Apocynaceae & Nithyakalyani & Juice with hot water used for Diabetes. \\
\hline
\end{tabular}

The dominant families with more number of medicinal plants in the present study are Euphorbiceae and Lamiaceae with 4 species and followed by Moraceae and Cucurbitaceae (each of three species).In the four families (Fabaceae (Leguminaceae), Acanthaceae, Malvaceae and Meliaceae) were documented 2 species of each. The rest are represented with one species each (Fig.3).

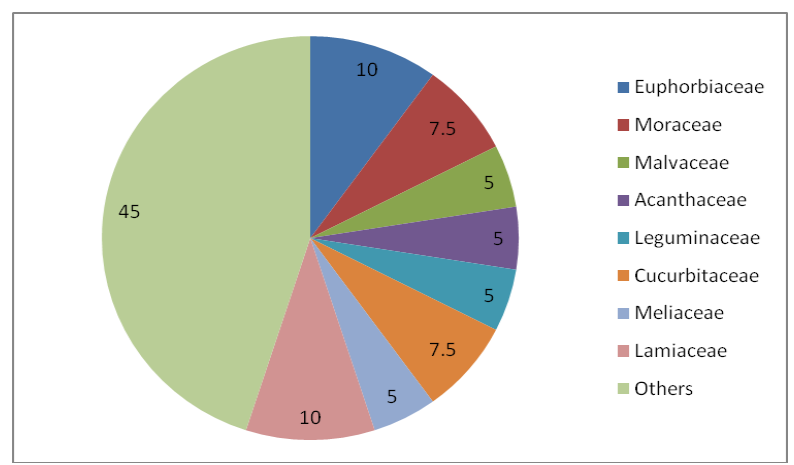

Fig.3. Percentile Analysis for distribution of plant families

Among the different plant habit used for the preparation of medicine, herb(47.5\%) were found to be the most frequently used plant habits in the preparation of medicine followed by shrubs (30\%), Climbers $(12.5 \%)$ and Trees $(10 \%)$. The herb and shrub are the two major plant habits which are frequently used for the treatment of various diseases by the Malayali tribe Jawadhuhills (Fig.4).

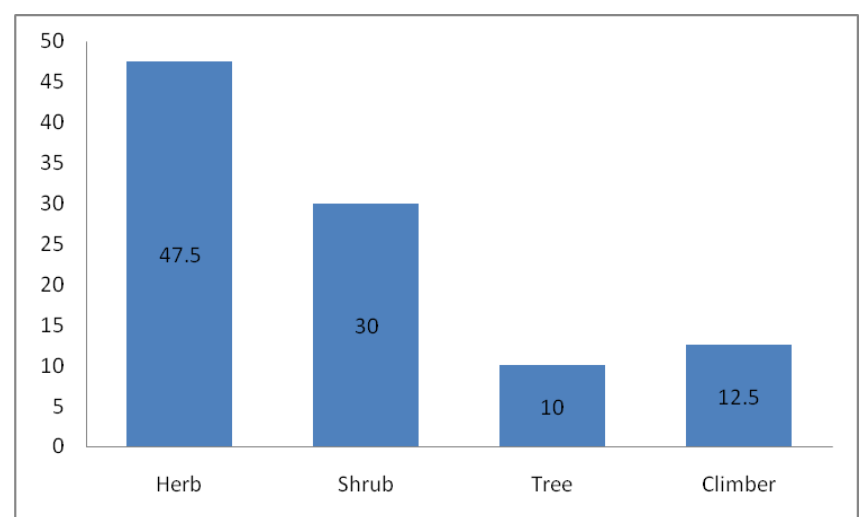

Fig.4. Analysis of plant habit with respect to preparation of medicine 


\section{Conclusion}

There is always a hunt for rich ethno botanical knowledge for ethno botanical studies of medicinal plants. The information gathered from the tribal is useful for the future researchers, biologist and scientist in the field of ethno botany and pharmacology. The present study reveals that the malayali tribes of the study area possess rich knowledge on the medicinal plants and their utilization. Lack of interest and awareness among the younger generation of malayali tribes we face the high risk of losing this vibrant knowledge in the near future. The study shows that knowledge and usage of herbal medicine for the treatment of various ailments among the malayali tribals, is still a major part of their life and culture of the villagers.

\section{Acknowledgement}

Authors very much thankful to the Malayali tribal people, those who are shared the valuable traditional and medicinal knowledge to us.

\section{References}

[1]. Aumeerudy, Y. Ethnobotany, linkages with conservation and development. Proceedings of first training workshop on Ethnobotany and its applications to conservation NARC, Islamabad, 1996; 152-157.

[2]. Diallo, D., B.Hveem, M.A. Mahmoud, G Betge, B.S Paulsen and A.Magia. An ethno botanical survey of herbal drugs of Gourma district, Mali, Pharmaceutical biol., 1999; 37:80-91.

[3]. Gamble, J.S. Flora of the Presidency of Madras. Allard \& Co. London (Reprinted -1956) Botanical Survey of India, Calcutta, 1963, Vol.I-III

[4]. Thurston, F and Rangachari, K. Castes and tribes of southern India. Government Press (Reprinted 1975).Cosmo Publication, New Delhi, India, 1909, Vol.IV

[5]. Jayasree, G. Impact of Development Programmes on The Malayali of Javadhu hills, Tamilnadu. Doctoral Dissertation. University of Madras, Chennai-5.

[6]. Jain, S.K. Methods and Approaches in ethnobotany.Society of Ethnobotany, Lucknow, India, 1986.

[7]. Gamble, J.S. The Flora of the Presidency of Madras, Londan: Adlard \& Sons Ltd, 1935.

[8]. Jain, S.K and Goel, A.K. A Manual of Ethnobotany. Scientific Publishers, Jodhpur, 1995

[9]. Jain, S.K. Medicinal Plants. National Book Trust, New Delhi India, 1979.

[10]. Jain, S.K. Medicinal Plants. National Book Trust, New Delhi India, 1979.

[11]. Jain, S.K. Ethnobotany in Modern India, Phytomorphology Golden Jubilee Issue: Trends in plants Sciences, 2000. 